\title{
MUSIC AND MOVEMENT ACTIVITIES IN SUPPORT OF SENSORY PROCESSING
}

\author{
Zuzana Fábry Lucká1, Mária Habalová \\ ${ }^{1}$ Dr., Comenius University, SLOVAKIA, lucka4@uniba.sk \\ ${ }^{2}$ Dr., Comenius University, SLOVAKIA, habalova@fedu.uniba.sk
}

\begin{abstract}
Through musical and movement activities, the child naturally obtains information from the outside world. If sensory processing is impaired, it might be difficult for a child to receive, understand and adequately respond to the stimuli that come through the senses. The aim of this study is to present different possibilities for the use of music and movement activities as a natural and enjoyable tool to support sensory processing in preschool children.
\end{abstract}

Keywords: Musical and movement activity. Preschool child, Sensory processing.

\section{MUSIC AND MOVENMENT}

Music and movement activities are an inseparable and at the same time natural part of free play from an early age. Such activities affect several senses simultaneously, they act in a multisensory manner. From an early age, children express themselves mainly through their own nonverbal expressions. Their own body becomes a tool through which not only various sensory stimuli enter but also exit. Through sensory reactions, children express their needs, whether it is general restlessness, screaming, crying, satisfied "spinning". The authentic experience of the child is a basic pillar for the relationship to one's own physicality.

\subsection{Music}

Music affects the child with its rhythm, timbre, pitch, melody, harmony and dynamics. In music, these elements are organized. It is the structure that distinguishes music from many other common sounds and allows one to predict and expect what will follow. In most cases, children respond to music very naturally, spontaneously and joyfully. Reactions evoked by music can manifest themselves on a somatic, cognitive, emotional, communicative and social level, with music acting in two basic ways - stimulating as well as calming. Due to this effect, it is possible to partially predict the effect of music based on these characteristics:

- Stimulating music - most often characterized by a faster tempo, strong rhythm, higher volume, more pronounced dynamic changes and contrasts, contains elements of gradation, staccato, variations of tones, sounds, melodies, etc.

- Soothing music - it is characterized by a slower tempo, small dynamic changes, lower volume, legato, etc. predictability is important here.

In connection with music-related activities, it is important to consider the duration of auditory stimuli. Sounds have a certain length and cannot be heard for a longer time (Vágnerová, 2005), and therefore participation in 
musical activities is highly dependent on the ability to focus on what is happening here and now. If the music ceases to be interesting or ends, children lose attention relatively quickly or shift it to something else. Different variations in music as well as in offered activities, can help to sustain attention. These new inputs increase attractivity of the possible monotonous stimulus, thus helping to keep the child's attention. These changes may cover the following areas:

- The music itself, where all the changes (in dynamics, tempo, volume) can be used to excite, arouse expectations, surprises, etc. This can help to sustain attention and improve concentration in the performance of tasks.

- New inputs and variations in ongoing activities which involve different sensory modalities. One of the most enjoyable media for conveying a lot of different sensory information is movement.

Music is often associated with movement, which represents the basis of a child's expression (Vodičková, 2020). The synthesis of the music rhythm and the rhythm of movement evokes a feeling of liberation, freedom, and creates favorable conditions for the mental activity of children.

\subsection{Movement}

Movement is all around us, it is a part of everyday life of a person of all ages (Szabová, 1998). It is the physical expression of the child in relation to the specific situations to which he or she is repeatedly exposed. Nevertheless, it is not just a summary of motor manifestations. It is unique, specific to different situations. Through movement, children show what relations they have with their surroundings, whether they are integrated into the environment or how they feel at the given moment.

Movement is important at every age (Zimmer, 2019). It accompanies the fetus from the intrauterine period first it cannot be felt on the outside, but later these movements take place in interaction with the mother. The fetus responds with movement to all external and internal changes, to the composition of the mother's diet, to her emotional mood, to different sound and later light stimuli from the environment. In such an early period the mother is still unable to differentiate the movements due to the fact that she cannot determine whether it is a manifestation of satisfaction or, conversely, dissatisfaction. After the birth, because in the neonatal period there is still no intelligible speech, children manifest nonverbally. They use components of nonverbal expression so their communication may be relatively difficult to understand. Especially at an early age these expressions are often understood only by close family members - mother or the father, and only after a reasonable time, based on the experience gained.

\subsection{Parallels between Musical and Physical Movement}

Music is an art that exists in space and time. Králová and Kantor (2020) describe the individual components of these planes as follows:

- The spatial plane of music is formed by melody, pitch, intensity, timbre, harmony, tonality, tectonics, and dynamics.

- The time plane consists of musical rhythm, meter, tempo, agogics and articulation.

Changes within these components that take place over the time are referred to as a musical movement. It is defined by changes in tempo, dynamic, gradation, ascending and descending series of tones, pauses, etc. All these changes help to sustain attention, raise expectations, or, conversely, contribute to reassurance and various other responses.

Similarly, the movement is realized in a certain time. Whether it is a specific independent movement or a movement sequence, the performance has its beginning, course, and goal. Like music, movement can flow, but it can also be interrupted, it can be coordinated, but it can also be inaccurate. Authors Kantor and Chrastina (2014) describe the parallels between music and movement in the following areas - intensity, tempo, length/endurance, range, and accuracy (Table 1).

Table 1: Parallels between music and movement

\begin{tabular}{|l|l|l|}
\hline & Music & Movement \\
\hline Intensity & Volume of tones or music & $\begin{array}{l}\text { The strength expended to perform a } \\
\text { movement }\end{array}$ \\
\hline
\end{tabular}


Proceedings of INTCESS 2022- 9th International Conference on Education \& Education of Social Sciences 17-18 January 2022- Online Conference

\begin{tabular}{|l|l|l|}
\hline Tempo & $\begin{array}{l}\text { The rate at which beats change over } \\
\text { time }\end{array}$ & $\begin{array}{l}\text { The speed at which the movement is } \\
\text { performed }\end{array}$ \\
\hline $\begin{array}{l}\text { Length/ } \\
\text { Endurance }\end{array}$ & $\begin{array}{l}\text { Length of individual tones and the song } \\
\text { as a whole }\end{array}$ & $\begin{array}{l}\text { The time required to perform a single } \\
\text { movement or motion sequence }\end{array}$ \\
\hline Range & $\begin{array}{l}\text { Distance from the lowest to the highest } \\
\text { pitch of voice, musical instrument, etc. }\end{array}$ & $\begin{array}{l}\text { Range of motion: stretching from flexion to } \\
\text { extension (distance and direction a join } \\
\text { can move) }\end{array}$ \\
\hline Accuracy & $\begin{array}{l}\text { Rhythmic and intonation accuracy, tone } \\
\text { quality }\end{array}$ & $\begin{array}{l}\text { Coordination and control of intentional } \\
\text { movement activities }\end{array}$ \\
\hline
\end{tabular}

Source: Kantor and Chrastina (2014)

Kováčová $(2021$, p. 17) states that "21. century considers art therapies to be a necessary and promising part of everyone's treatment." Therefore, focusing on music and movement gains increasing importance in supporting children's development.

\section{CHILDREN'S DEVELOPMENT IN THE CONTEXT OF MUSIC, MOVEMENT AND SENSORY PROCESSING}

In the period after birth, children are able to perceive sounds, but from the offer of sensory stimuli, they prefer taste, olfactory, somatic (touch, pain, warmth) and vestibular stimuli. They respond to various stimulation from the external and internal environment primarily through reflexes. These represent certain automatic answers and reactions of the organism and ensure the survival of the child and the satisfaction of their basic needs. The developmentally conditioned interaction of maturation and learning is manifested by the gradual replacement of reflexive (subcortical) behavioral control with its conscious and deliberate (cortical) control (Vágnerová, 2005). In this early period, children are fully dependent on their caregivers to meet their physiological needs as well as to stimulate them appropriately. Under normal circumstances, the need for stimulation is saturated within a normal environment and appropriate parental behavior. The importance of adequate stimulation is emphasized by Matějček (2005), who states that individual stimuli should come in adequate quantity and quality. Children receive the stimuli and process them at their developmental level. Ideally, the stimuli are strong and proportionate enough. Then, children encounter their environment, and their alertness (readiness for action) is activated. In the case of excessive stimulation, this leads to fatigue and defensive reactions (avoidance reactions, rejection). A problem also occurs when the stimuli are too weak or there is a lack of them. In such case, the child's development may be endangered.

One of the ways mothers meet the needs of their children is singing lullabies, which often calms the baby. Especially for young children, more important than singing itself is the connection of the spoken word (singing) with touch and maternal proximity. By taking care, the mother naturally conveys many sensory stimuli through feeding, touching, caring, rocking, and talking to the child. Gradually, in the third month of life, due to the growing interest in sounds - according to Krbat'a (2008) this is referred to as auditory dominance - they also show an increasing interest in sounds coming from the outside environment. They listen intently, try to analyze the sound, while responding to perceived stimuli with movement (by fixing their eyes, turning, reaching towards interesting objects etc.). At about the age of six months, children begin to respond to music with body movements such as rhythmic swaying and rocking (Moog, 1976). Gradually, as they can use their hands purposefully, they show an increasing interest in manipulating various objects in a targeted way. And as they begin to understand the concept of cause and effect, they may be attracted by toys and instruments that, for example, make sound. With the onset of independent mobility, children can move and discover interesting things in their environment on their own. In the following years, they will progress in all areas physically, mentally, intellectually, emotionally, socially. With the development of motor skills and interest in other people, children like to participate in various music and movement activities.

Problems in sensory processing can be manifested by difficulties in gaining experience, attention disorders, challenging behavior, inability to integrate into society, learning difficulties, etc. It is in movement expression that the first problems in a child's behavior are most often reflected, which can be recognized in three polarities - submissive, ambivalent, and aggressive expression.

Health and its abnormalities are an important factor in the application of any development support. 
Recognition of deviations in development, the possibility of its support, are an area that requires professional awareness. Development and its deviations are important especially in the intervention at an early age of the child, but also in the older age due to the biographical method of processing client data. The specifics of this pillar are important especially if the development is uneven and it is important for the expert to know about the possibilities and limitations of the development potential of the individual (Barton et al., 2015).

Sensory elements are naturally part of children's play at an early age. Children naturally seek out various stimuli from the environment, which allow them to better understand their play or the situation that is currently taking place. Sensory processes therefore take place naturally, they cannot be omitted from the play as the basic unit of the child's activity. Their functionality is a prerequisite for expression, which is expression of the relationship between verbal and nonverbal expression, its interconnectedness in the context of visual, acoustic, haptic perception, imagination, or speech (Slavík, 2009).

Sensory processing is a prerequisite for obtaining a comprehensive perception from the environment. Individual differences in the functioning of sensory systems are reflected in the sensitivity to stimuli, as well as in the behavioral responses to them and in the ability to adapt behavior to acting stimuli when performing practical activities (Lesner Lištiaková, 2017).

If the child's disorder in sensory processing manifests clinically, it is necessary to respond to this fact. Problems in sensory processing can manifest itself in individual sensory systems, which are:

- Visual system;

- Auditory system;

- Tactile system;

- Olfactory system;

- Proprioceptive system;

- Vestibular system.

Knowledge of sensory processes and strategies to support them leads to a better understanding of the child. It allows the care givers and professionals to adjust the conditions and environment to provide the child with space for gaining experiences and learning. One solution is to adjust the child's environment. Thus, it is a specifically adapted space in which stimuli supporting several sensory pathways are used at the same time, it is multisensory, usable for a wide range of sensory-oriented activities (Fowler, 2007).

\section{MULTISENSORY STIMULATION}

Music is made up of sounds that the human body can perceive through hearing and vibration. Auditory perception is also supported throughout the development by multisensory perception and interconnection of selected sensory modalities (e.g., in the localization of sounds by hearing, sight plays an important strengthening function) (Nakonečný, 1998). Along with sight, other sensory systems, such as tactile, kinesthetic, and proprioceptive, are often involved in mediating the musical experience in musical activities. Their involvement depends on the focus and content of the activities offered, which are deliberately mediated to the child.

Multisensory approaches are applied in the context of a therapeutic intervention when it is assumed that by the offer of suitable sensory stimuli it is possible to mitigate the impact of damage or disability or to achieve an improvement in the somatic or mental state of the individual. In these approaches, the emphasis is on conveying and organizing meaningful sensory stimuli, often using multiple sensory pathways at the same time. The choice of stimuli depends on the child's individual preferences or on an intervention plan based on their specific needs. In therapy, it is appropriate to support sensory processing in a way that mimics natural development and choose stimuli that:

- The child can perceive at their developmental level,

- Which are sufficiently interesting and attractive for the child,

- Which can be partially changed to help keep the child's attention.

When evaluating children's reactions to the activities offered, it is also necessary to consider that in the case of developmental issues, the observable manifestations may be relatively insignificant or delayed (Schwartz, 2008). 


\subsection{Multisensory Environment}

This environment is specific in that it has a relaxing, activating, stimulating effect on a person, depending on the selected components used and the overall atmosphere of the room. A multisensory environment is an environment where there is a multiplication of stimulation through specific stimuli at one time. It is used in both individual and group form and provides a wide range of possibilities for self-expression in a way that is easy for children to grasp and understand. Multisensory environment is multi-stimulating. This is an environment prepared for the children, in which they are exposed to various stimuli from the environment, but they also have the opportunity to actively participate in play within its means and limits. Fowler (2007) states that the multisensory environment is specific to the wide range of sensory activities that can take place in it.

\section{MUSIC AND MOVEMENT ACTIVITIES IN SUPPORT OF SENSORY PROCESSING}

Movement is a natural reaction that arises because of external and internal stimuli. It is associated with every conscious reaction of the child and at the same time through it the child penetrates and gets acquainted with the environment that surrounds them.

In music and movement activities, music (especially its rhythmic component) is combined with various movements. Enriching music with movement increases its attractiveness. In this case, music can be used in both receptive and active forms of therapy. In the receptive form, children do not create the music by themselves, but they listen to it (or perceive it through other sensory channels) and respond to it with movement. In active form, children are actively participating in music production that means, that they sing or play a musical instrument. Here, too, they perform targeted movements that can be used as motivation in training of functional movements.

\subsection{Vocal Activities and Movement}

The human voice can also be one of the means used in therapy. Each person's vocal expression is individual, characterized by its specific timbre, melody, and tempo. When talking or singing, subtle vibrations are created, which can be felt by touching the throat and chest. By using the voice, the therapist imparts something personal and authentic to the therapy process (Fábry Lucká, 2017).

When working with children, musical vocal activities are most often associated with singing. Initially, children are listeners and gradually become acquainted with the songs they hear repeatedly on a receptive level. They show their interest through visual contact and various (also movement) manifestations of joy. As they gradually gain control of their movements, they try to imitate accompanying gestures, engage in action songs, and dance.

Within the direct interaction, it is possible to adapt and vary the offered songs - e.g., change the timbre of the voice, position of the voice, tempo of the song (fast / slow), dynamics (quiet / loud), gradation (gradual changes of tempo and dynamics), use instrumental accompaniment, or movement expression. Children can then respond to these changes with their movement, for instance they move slowly in reaction to slow tempo of the song, or they use wider range of movements with loud singing.

The singing of a song is often accompanied by body percussion (clapping hands, snapping fingers, slapping feet, or stomping feet). According to Mátejová and Mašura (1992) the child is aware of movements through various sensory channels: acoustically (perceives sounds), visually (for example, eye-hand coordination), tactilitly (is aware of contact with different parts of the body), kinesthetically (perceives changes in limb position, is aware of the strength needed to perform movement). The combination of movement and musical rhythm leads to a better awareness of rhythm and to rhythmic-movement synchronization.

\subsection{Activities with Musical Instruments}

In the first years of life, cognition and learning take place through direct contact with the real world. Children think within presence and get acquainted with what they perceive or what they can manipulate (Vágnerová, 2005).

Handling musical toys and instruments is fascinating and interesting. For a child, this is a play in the true sense of the word. Musical instruments attract attention both by their sound and appearance. They can have different shapes, sizes, or be made of interesting materials. Through all this, they convey many sensory experiences and at the same time give children the opportunity to experiment with sounds during manipulation and play. In this case, the musical instruments act as motor stimulators. 
In the area of gross motor skills, it is possible to practice the coordination and accuracy of performing movements through musical instruments variously placed in the room setting. This way the play is intentionally designed to train the required movements. The child learns and improves the ability to coordinate their movements through sight (eye-hand coordination, or another part of the body) as they visually perceive a musical instrument as the goal to which the movement is directed. At the same time, they receive immediate auditory and kinesthetic feedback during movement and contact with the instrument (Hurt-Thaut \& Johnson, 2017). Such an activity can take the form of a game and encourage the child to engage in the targeted motor activity.

In the area of fine motor skills, it is possible to use musical instruments to practice various grips. Of course, in addition to targeted activities, it is good to leave the child space for free experimentation and spontaneous play with objects that arouse their interest. Musical instruments have different shapes and designs, and even the manipulation with them (hand-to-hand translation, mutual administration with a child) can be used to improve the functional handling and coordination of hand movement.

\subsection{Music and Movement Games}

After the child starts walking independently, the rhythm and melodies become part of simple musicmovement games. Children's songs are often accompanied by body play, gestures, elements of dance. Due to their attractiveness, they are a very good means of improving movement coordination and differentiation, balance, and other motor skills, while at the same time mediating a number of proprioceptive and vestibular stimuli. They are often realized in interaction with an adult or other children.

Music and movement games often include distinctive sound signals. These strong sounds (such as a drum beat) are usually part of an ongoing activity / game. They are often followed by quick reactions, as they vary or change the course of the game according to pre-agreed rules (Mátejová \& Mašura, 1992).

When planning and implementing music and movement games, it is appropriate to use:

- Various massages,

- Tactile activities accompanied by music production (vocal expression, reproduced music),

- Family games and rituals,

- Simple movement games, non-verbal games, and exercises,

- Ritual body games,

- Games with changing the position of the body in space,

- Activities to support proprioceptive system,

- Activities to support vestibular perception - swinging, jumping.

\section{CONCLUSION}

Sensory systems interconnect and influence each other. Therefore, it is necessary to know their specifics in relation to a particular child and their autobiography. The approach to a child with a sensory processing disorder requires, in particular, knowledge of sensitivity, in relation to hypersensitivity versus hyposensitivity. In the case of hypersensitivity, sensory strategies consist of the removal of disturbing elements in the environment, on the contrary, in the case of hyposensitivity, it is necessary to provide stimulation through stimuli to an increased extent. In both cases, it is necessary to work with the degree and intensity of stimulation with respect to the specific specifics of the child and their sensory profile. The readiness of the environment is thus a basic attribute of a successful therapeutic intervention, in which it is possible to use a multisensory play combined with movement and music so that adults can make it easier for the child to orientate in space and time, concentration, but also in social groups at older age.

\section{REFERENCE LIST}

Barton, E. E., Reichow, B., Schnitz, A., Sherlock, D. (2015). A systematic review of sensory-based treatments for children with disabilities. Research in Developmental Disabilities. 37: 64-80. doi: 10.1016/j.ridd.2014.11.006. 
Fábry Lucká, Z. (2017). Expresivita v multisenzorických prístupoch. In Expresívne terapie vo vedách o človeku. Ružomberok: Verbum. 2017. ISBN 978-80-561-0473-6.

Fowler, S. (2007). Sensory stimulation: Sensory Focused Actvities for People with Physical and Multiple Disabilities. London and Philadelphia: Jessica Kingsley Publishers, 2007. ISBN 978-1-84310-455-1

Hurt-Thaut, C. P., Johnson, S. B. (2017). Neurologic Music Therapy. In: Wheeler, B. L. (eds.), 2017. Music Therapy handbook. New York: The Guildford Press. s. 220 - 232. ISBN 978-1-4625-2972-8.

Kantor, J., Chrastina, J. (2014). Sebaobsluha a trénink pohybových funkcí u osob s těžkým kombinovaným postižením. In: Kantor J. (ed.) 2014. Kretivní přístupy v rehabilitaci osob s těžkým kombinovaným postižením. Olomouc: Univerzita Palackého v Olomouci. ISBN978-80-244-4358-4.

Kováčová, B. (2021) Expresia vo výchove. In Valachová, D., Kováčová, B. (Eds). Expresivita vo výchove IV. Bratislava: Univerzita Komenského. 2021. ISBN 978-80-223-5265-9.

Králová, E., Kantor, J. (2020). Hudobná terapia v rámci fyzioterapie. Trenčín: Trenčianska univerzita Alexandra Dubčeka v Trenčíne. ISBN 978-80-8075-932-2.

Krbat'a, P. (2008). Kontext hudobno - ontogenický. In Krbat'a, P. a kol. 2008. Psychológia hudby nielen pre hudobníkov. Varín: Elektro AB, s. 125 - 154. ISBN 978-80-969808-6-4.

Lessner Lištiaková, I. (2017). Multisenzorické prístupy. In: Lessner Lištiaková, I, (Ed.). 2017. Multisenzorické aspekty liečebnopedagogických terapií. Bratislava: Univerzita Komenského v Bratislave. ISBN 978-80223-4476-0.

Mátejová, Z., Mašura, Z. (1992). Muzikoterapia v špeciálnej a liečebnej pedagogike. Bratislava: SPN. ISBN 80-08-00315-4

Matějček, Z. (2005). Prvních 6 let ve vývoji a výchově dítěte. Praha: Grada. ISBN 80-247-0870-1.

Moog, H. (1976). The musical experienceof the Pre-school Child. London: Schott. ISBN 978-0901938060. Zdroj: BUNT, L. 1994. Music Therapy. An art beyond words. London: Routledge. ISBN 0-415-08703-1.

Nakonečný, M. (1998). Základy psychologie. Praha: Academia, 1998. ISBN 80-200-1290-7.

Schwartz, E. (2008). Music Therapy, and Early Childhood: a Developmental Approach. Barcelona: Barcelona Publishers. ISBN 978-1-891278-53-2.

Slavík, J. (2009). Expresivita, výraz a transparentní znak jako prostředky terapie a výchovy. In Valenta, M. Rukovět dramaterapie II. Olomouc: Univerzita Palackého v Olomouci, 2009.

Szabová, M. (1998). Náčrt psychomotorickej terapie. Bratislava: Pedagogická fakulta Univerzity Komenského, 1998. ISBN 80-88868-06-8.

Vágnerová, M. (2005). Vývojová psychologie 1. Praha: Karolinum, 2005. ISBN 80-246-0956-8.

Vodičková. B. (2020) Od psychomotorickej expresie cez psychomotorickú výchovu k psychomotorickej terapii. In Kováčová, B., Valachová, D. Expresivita v (art)terapii III. Bratislava: Univerzita Komenského. 2020. ISBN 978-80-223-5021-1.

Zimmer, R. (2019). Handbuch Psychomotorik. Zlín: Graspo CZ., 2019. ISBN 978-3-451-3858-3. 